\title{
A LITERATURE REVIEW : PENGARUH PERBEDAAN PELARUT EKSTRAK JANTUNG PISANG (Musa paradisiaca) SEBAGAI GALAKTOGOGUM
}

\section{A literature Review : The Effect of Differences of Musa paradisiaca Flower Extract Solvens (Musa paradisiaca) as a Galactogogue}

\author{
Andriani Noerlita Ningrum ${ }^{1}$, Nova Rahma Widyaningrum ${ }^{2}$, \\ Etik Sulistyorini $^{3}$ \\ STIKES Mamba'ul Ulum Surakarta \\ andrianinoerlita.n@gmail.com
}

\begin{abstract}
ABSTRAK
Latar Belakang: Salah satu cara yang dapat dilakukan untuk meningkatkan produksi ASI adalah dengan meningkatkan produksi hormon prolaktin menggunakan zat galaktogogum. Menurut penelitian sebelumnya, jantung pisang (Musa paradisiaca) mengandung alkaloid, saponin, glikosida, tanin, flavanoid dan steroid. Perlu diteliti apakah ekstrak jantung pisang (Musa paradisiaca) terbukti secara ilmiah memiliki efek galaktogogum dan pengaruh perbedaan pelarut yang digunakan dalam memberikan efek galaktogogum.

Tujuan penelitian: Mengetahui apakah ekstrak jantung pisang (Musa paradisiaca) terbukti secara ilmiah memiliki efek galaktogogum dan pengaruh perbedaan pelarut yang digunakan dalam memberikan efek galaktogogum.

Metode: Jenis penelitian ini adalah kajian literatur (literature review) dengan menelusuri database PubMed dan Google Scholar menggunakan kata kunci 'galactogogue and musa paradisiaca and lactating and rat' dan 'laktasi and laktagogum and air susu and pisang and musa paradisiaca dan tikus'.

Hasil: Dari penelusuran peneliti menemukan 68 jurnal yang sesuai dengan kata kunci tersebut. 20 jurnal di eksklusi karena tidak tersedia free full text. Asesmen kelayakan terhadap 48 jurnal free full text dilakukan, 46 jurnal dieksklusi karena tidak sesuai kriteria inklusi, sehingga diperoleh 2 jurnal full text yang direview.

Simpulan: Jantung pisang (Musa paradisiaca) memiliki efek sebagai galaktogogum. Perbedaan pelarut yang digunakan dalam ekstraksi mempengaruhi efek galaktogogum yang ditimbulkan. Efek galaktogogum paling besar diperoleh pada ekstrak air jantung pisang (Musa paradisiaca) terutama dalam bentuk aglikon dari ekstrak air.
\end{abstract}

Kata Kunci: Musa paradisiaca, Galaktogogum, Literature Review

\section{ABSTRACT}

Background: One way that can be done to increase milk production is by increasing the production of the hormone prolactin using galactogum substances. According to previous research, Musa paradisiaca contains alkaloids, saponins, glycosides, tannins, flavonoids and steroids. It needs to be investigated whether 
Musa paradisiaca is scientifically proven to have a galactogum effect and the effect of different solvents used to provide a galactogum effect.

Research purposes: Knowing whether banana flower extract (Musa paradisiaca) is scientifically proven to have a galactogum effect and the effect of different solvents used to provide a galactogum effect.

Methods: This type of research is a literature review by browsing the PubMed and Google Scholar databases using the keywords 'galactogogue and musa paradisiaca and lactating and rat' and 'lactation and lactagogum and milk and banana and musa paradisiaca and mice'.

Results: From the search, the researchers found 68 journals that match these keywords. 20 journals were excluded because free full text was not available. The feasibility assessment of 48 free full text journals was carried out, 46 journals were excluded because they did not meet the inclusion criteria, so that 2 full text journals were reviewed.

Conclusion: Banana heart (Musa paradisiaca) has an effect as a galactogum. The different solvents used in the extraction affect the effect of galactogum. The effect of galactogum was greatest in the water extract of banana heart (Musa paradisiaca), especially in the form of aglycone from water extract.

Keywords: Musa paradisiaca, Galactogogue, A Literature Review

\section{PENDAHULUAN}

Air Susu Ibu (ASI) adalah makanan terbaik untuk bayi karena mengandung banyak sekali nutrisi yang dibutuhkan oleh bayi. Kandungan nutrisi dalam ASI diantaranya yaitu protein dan imunoglobulin. Protein (asam linoleate dan folasin) dalam ASI berperan terhadap pembentukan sel-sel otak yang mempengaruhi perkembangan otak. Kandungan immunoglobulin dalam kolostrum berperan sebagai antibodi untuk melawan infeksi sampai sistem kekebalan bayi mulai berfungsi (Martin, C.R., et. al., 2016). World Health Organization (WHO) merekomendasikan pemberian ASI pada 6 bulan pertama kehidupan dilanjutkan sampai setidaknya 2 tahun. Pemberian ASI yang optimal dapat berpengaruh pada pertumbuhan, perkembangan dan kesehatan pada masa neonatal. Pentingnya menyusui bagi ibu adalah dapat menurunkan berat badan, membentuk ikatan secara emosional dengan bayi, mencegah kanker payudara, sebagai kontrasepsi alami dan juga ekonomis. Manfaat menyusui untuk bayi dapat meningkatkan ikatan dengan ibu sekaligus tercukupinya kebutuhan nutrisi dan emosi (Penagos, et.al., 2014).

Banyak masalah yang timbul saat proses menyusui, salah satunya adalah kurangnya produksi ASI. Faktor- faktor yang menyebabkan berkurangnya produksi ASI diantaranya yaitu faktor psikologis dan faktor fisik ibu. Faktor psikologis dapat berupa stress, khawatir dan kondisi ibu yang tidak bahagia selama periode menyusui. Faktor fisik ibu seperti sakit, lelah, menggunakan 
pil/alat kontrasepsi yang mengandung hormon, ibu menyusui hamil lagi, atau ibu dengan kelainan anatomis payudara juga dapat mengurangi produksi ASI. Kegagalan dalam menyusui juga umum terjadi pada wanita post partum, sehingga kurangnya produksi ASI menjadi alasan utama untuk menyapih lebih dini. Menurut Padma LL., et.al., (2014) setidaknya 5\% wanita mengalami kegagalan menyusui (agalaktia) dan sekitar $15 \%$ wanita mengalami kurangnya produksi ASI (hipogalaktia) pada 3 minggu post partum.

Salah satu upaya mengatasi masalah produksi ASI yaitu dengan penggunaan galaktogogum yaitu substansi yang dapat menginisiasi, memelihara dan menambah produksi ASI. Galaktogogum memperantarai peningkatan hormon prolaktin yang berperan penting dalam produksi ASI. Galaktogogum sintetis yang paling sering digunakan adalah klorpromazin, sulpiride, metoklopramid dan domperidone. Akan tetapi penggunaan jangka panjang berkaitan dengan kejadian efek samping yang tidak diinginkan salah satunya yaitu efek ekstra piramidal baik pada ibu maupun bayi (Bekoe E.M., et.al., 2018). Maka dari itu eksplorasi senyawa bahan alam terus dikembangkan untuk memenuhi kebutuhan galaktogogum yang lebih dapat diterima dengan efek samping yang minimal.

Eksplorasi tanaman yang mengandung efek galaktogogum telah banyak diteliti sebelumnya seperti fenugreek, bunga lawang, silymarin, asparagus, daun katuk dan daun pepaya. Tanaman-tanaman tersebut banyak digunakan untuk meningkatkan produksi ASI baik dikonsumsi secara langsung maupun digunakan sebagai bumbu tambahan dalam makanan (Zapantis, A., et.al., 2012).

Indonesia merupakan Negara penghasil pisang terbesar ke tiga di dunia, yang menghasilkan 7,62 juta ton pisang per tahun. Pisang merupakan komoditas unggulan buah-buahan tahunan di tahun 2018 yang diproduksi hampir di setiap provinsi di Indonesia. Provinsi penghasil pisang terbesar di Indonesia adalah Jawa Timur, Lampung, Jawa Barat, Jawa Tengah dan Bante (Badan Pusat Statistik, 2018). Semua komponen pisang dapat dimanfaatkan oleh masyarakat, mulai dari bonggol, batang, pelepah, daun, buah bahkan jantung pisangnya. Bagian tanaman pisang yang masih kurang pemanfaatannya adalah jantung pisang. Secara tradisional, jantung pisang digunakan untuk meringankan sakit jantung, asma, diabetes mellitus, menoragia, nyeri pada saat menstruasi dan kram perut (Sumathy, V., et.al., 2011).

Menurut penelitian sebelumnya, jantung pisang (Musa paradisiaca) mengandung alkaloid, saponin, glikosida, tanin, flavanoid dan steroid dimana kandungan tersebut pada tanaman rosella (Hibiscus sabdariffa L.) dikaitkan dengan aktivitasnya dalam meningkatkan serum prolaktin yaitu hormon yang mempengaruhi produksi air susu (Okasha, et.al, 2008). Sampai saat ini penelitian ilmiah tentang efek galaktogogum ekstrak jantung pisang masih sangat terbatas. Belum diketahui pula senyawa aktif dari ekstrak jantung pisang yang bertanggung jawab terhadap efek galaktogogum. Penelitian ini membandingkan pengaruh perbedaan pelarut ekstrak jantung pisang (Musa paradisiaca) sebagai galaktogogum. Manfaat yang didapat dari penulisan literature review ini yaitu dapat menjadi bahan referensi dalam memilih pelarut yang efektif untuk jantung pisang (Musa paradisiaca) sebagai galaktogogum. 


\section{METODE PENELITIAN}

Jenis penelitian ini adalah kajian literatur (literature review), melalui penelusuran artikel publikasi pada PubMed dan Google Scholar. Literature review ini menggunakan literatur tahun 2010 - 2020 yang dapat di akses fulltext dalam format pdf. Kriteria jurnal yang di-review adalah artikel jurnal penelitian berbahasa Inggris dan Indonesia dengan subyek tikus betina yang menyusui, jenis jurnal artikel penelitian bukan literature review dengan tema pengaruh perbedaan pelarut ekstrak jantung pisang (Musa paradisiaca) dalam memberikan efek galaktogogum. Jurnal yang sesuai dengan kriteria inklusi dan terdapat tema pengaruh perbedaan pelarut ekstrak jantung pisang (Musa paradisiaca) dalam memberikan efek galaktogogum kemudian dilakukan review.

Data pada penelitian ini diambil dan dikaji 2 penelitian yang sesuai dengan kriteria inklusi.

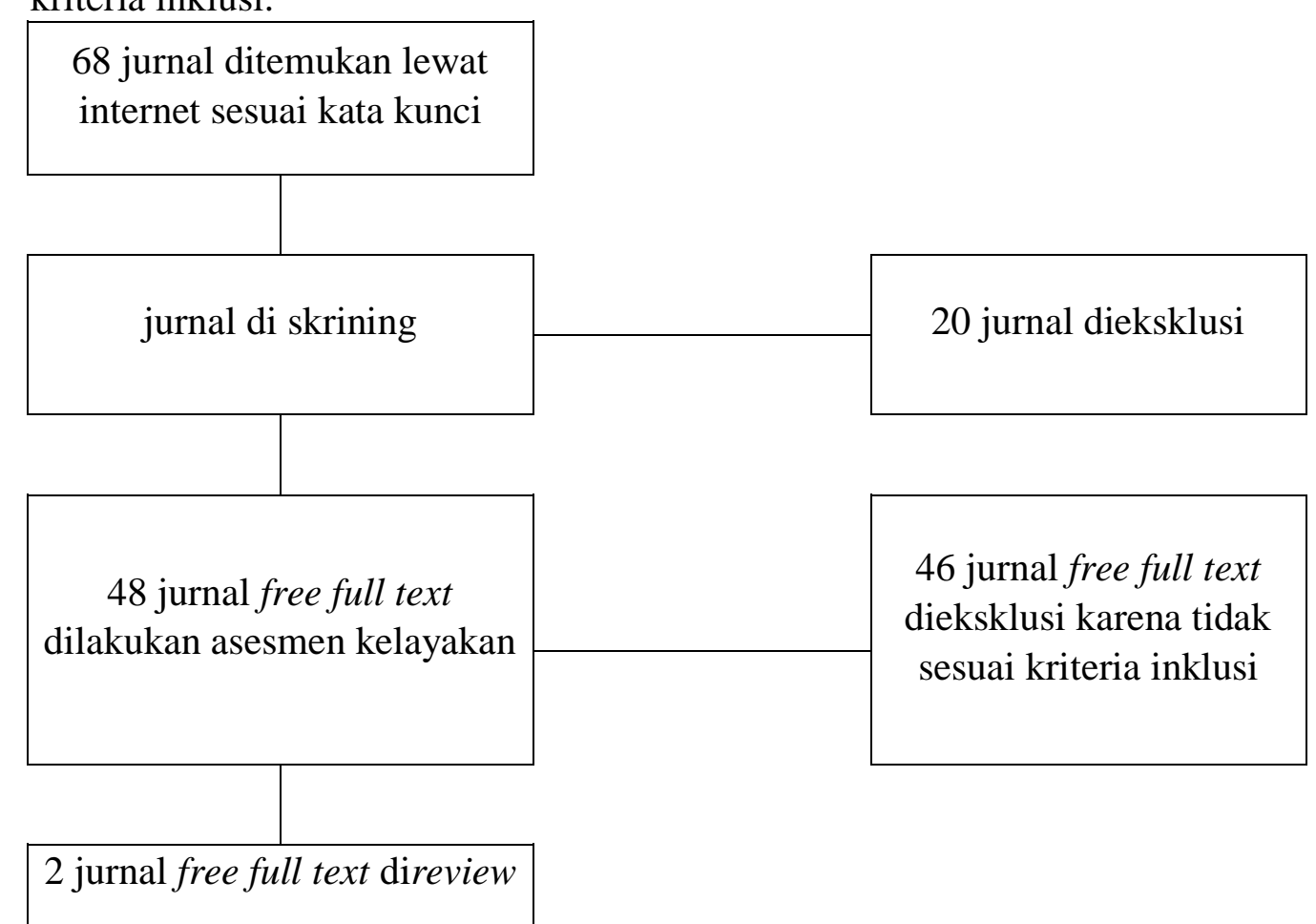

Gambar 1. Diagram Alur Penelusuran Jurnal

HASIL DAN PEMBAHASAN

\section{Hasil}

Pada pencarian melalui database PubMed dan Google Scholar menggunakan kata kunci 'galactogogue and musa paradisiaca and lactating and rat' dan 'laktasi and laktagogum and air susu and pisang and musa paradisiaca dan tikus', peneliti menemukan 68 jurnal yang sesuai dengan kata kunci tersebut. Sebanyak 20 jurnal di eksklusi karena tidak tersedia full text dan berbayar. 
Asesmen kelayakan terhadap 48 jurnal full text dilakukan, 46 jurnal di eksklusi karena duplikasi dan tidak sesuai kriteria inklusi, sehingga diperoleh 2 jurnal full text yang direview :

1. Mahmood A, Omar MN, Ngah N, 2012, Galactogogue Effects of Musa x paradisiaca Flower Extract on Lactating Rats. Asian Pacific Journal of Tropical Medicine (2012): 882-886

2. Mahmood A, Salihah N, Omar MN, Ngah N, 2017, Lactogenic Effects of Tannin and Aglycone Form of Aqueous Extract (AFAE) from Musa $x$ paradisiaca Flower on Lactating Rats. Malays. Appl. Biol. (2017), 46(3) : 9 14

Tabel 1. Karakteristik Artikel yang digunakan

\begin{tabular}{|c|c|c|c|}
\hline \multicolumn{2}{|c|}{$\begin{array}{l}\text { Karakteristik } \\
\text { Studi }\end{array}$} & Mahmood A, et. al., 2017 & Mahmood A, et. al., 2012 \\
\hline \multicolumn{2}{|c|}{ Jenis Penelitian } & Eksperimental & Eksperimental \\
\hline \multicolumn{2}{|c|}{ Perlakuan } & Aglikon dari ekstrak air & Ekstrak petroleum eter \\
\hline & & Tanin terkondensasi & Ekstrak etanol \\
\hline & & Ekstrak air & Ekstrak air \\
\hline \multirow[t]{2}{*}{ Kontrol } & Positif & Metoklopramid & - \\
\hline & Negatif & Akuades & Akuades \\
\hline \multirow[t]{4}{*}{$\begin{array}{l}\text { Hewan } \\
\text { uji }\end{array}$} & Jenis & Tikus betina galur Sprague Dawley & $\begin{array}{l}\text { Tikus betina galur Sprague } \\
\text { Dawley }\end{array}$ \\
\hline & Usia & 3 bulan & 3 bulan \\
\hline & BB & 200 - 350 gram & 200 - 350 gram \\
\hline & Jumlah & 30 & 20 \\
\hline \multicolumn{2}{|l|}{ Tempat } & Malaysia & Malaysia \\
\hline \multicolumn{2}{|c|}{ Lama pengamatan } & 10 hari laktasi & 10 hari laktasi \\
\hline \multicolumn{2}{|l|}{ Metode } & Weight-Suckle-Weight & Weight-Suckle-Weight \\
\hline \multirow{2}{*}{\multicolumn{2}{|c|}{ Luaran (outcme) }} & Produksi air susu & Produksi air susu \\
\hline & & Peningkatan berat badan anak tikus & $\begin{array}{l}\text { Peningkatan berat badan anak } \\
\text { tikus }\end{array}$ \\
\hline
\end{tabular}

Parameter yang diukur untuk membandingkan efek galaktogogum adalah produksi susu dan peningkatan berat badan anak tikus.

Mahmood A., et. al. (2012) dalam penelitiannya membandingkan efektivitas ekstrak petroleum eter, etanol dan air dari jantung pisang dalam memberikan efek galaktogogum. Hasil penelitian menyebutkan bahwa rataan produksi susu tikus selama laktasi hari ke-6 sampai hari ke-15 kelompok ekstrak air, petroleum eter, kontrol, dan etanol secara berurutan sebesar $(4,62 \pm 2,45)$, 
$(4,37 \pm 1,93),(3,69 \pm 1,79)$, dan $(3,65 \pm 1,89)$ g/anak/hari. Rendemen susu ekstrak air memberikan perbedaan signifikan dibandingkan kelompok kontrol (P $<0,05)$. Secara statistik, jumlah produksi susu pada tikus yang diberi perlakuan ekstrak petroleum eter tidak memberikan perbedaan signifikan dibandingkan kelompok kontrol dan ekstrak air. Kelompok ekstrak etanol tidak memberikan perbedaan dari kelompok kontrol selama periode perlakuan. Total produksi susu tikus selama 10 hari pengamatan masa laktasi kelompok ekstrak air, petroleum eter, kontrol dan etanol secara berurutan sebesar 217,27; 214,25; 177,31; dan 178,93 g. Hasil ini menunjukkan nilai rendemen total produksi susu pada berbagai ekstrak lebih tinggi dibandingkan rendemen total produksi kelompok kontrol $(177,31 \mathrm{~g} / 10$ hari) $(\mathrm{P}<0,05)$. Secara relatif, kelompok perlakuan ekstrak air dan petroleum eter memproduksi susu lebih besar 25\% dan 18\% dibandingkan dengan kelompok kontrol. Produksi susu yang dihasilkan kelompok perlakuan ekstrak etanol sedikit lebih rendah $(-1 \%)$ dibandingkan kontrol.

Penelitian ini juga mengukur perbandingan antara berat awal dan berat badan akhir, dan peningkatan berat badan anak tikus. Peningkatan berat badan tersebut adalah $(1.85 \pm 0.49),(1.78 \pm 0.56),(1.65 \pm 0.46)$ dan $(1.56 \pm 0.42) \mathrm{g} / \mathrm{anak}$ tikus berturut-turut pada kontrol, ekstrak air, ekstrak etanol dan ekstrak petroleum eter. Hasil penelitian menjelaskan bahwa tikus yang mendapat perlakuan ekstrak air tidak memberikan hasil yang berbeda signifikan pada peningkatan berat badan anak tikus dibandingkan dengan kelompok kontrol $(\mathrm{P}<0.05)$, meskipun menunjukkan peningkatan yang lebih tinggi dibanding ekstrak lainnya.

Pada penelitian selanjutnya, Mahmood A., et. al. (2017) membandingkan efek galaktogogum pada ekstrak air, aglikon dari ekstrak air (AFAE), dan tanin terkondensasi (CT), menggunakan kontrol positif metoklopramid dan kontrol negatif akuades. Hasil penelitian menunjukkan bahwa ekstrak air menghasilkan rataan produksi susu tertinggi, diikuti AFAE, metoklopramid, CT dan kontrol negatif berturut-turut sebesar $(4.86 \pm 2.36),(4.65 \pm 1.67),(3.76 \pm 2.25),(3.68 \pm$ $2.15)$, dan $(3.63 \pm 2.10) \mathrm{g} / \mathrm{anak} / \mathrm{hari}$. Produksi susu pada tikus yang mendapat perlakuan ekstrak air dan AFAE berbeda signifikan dibandingkan dengan kontrol negatif. Sedangkan tikus yang diberi perlakuan dengan CT menunjukkan produksi susu yang tidak berbeda signifkan dibandingkan dengan kontrol negatif.

Penelitian ini juga menunjukkan peningkatan berat badan anak tikus selama 10 hari pengamatan dari yang paling besar berturut-turut pada kelompok ekstrak air, AFAE, kontrol negatif, metoklopramid, dan CT sebesar $(1.85 \pm 0.47)$, $(1.72 \pm 0.35),(1.42 \pm 0.51),(1.36 \pm 0.71),(1.28 \pm 0.65)$ g/anak tikus Meskipun berat badan akhir anak tikus pada seluruh kelompok perlakuan sebanding, akan tetapi secara statistik peningkatan berat badan antar kelompok berbeda signifikan. AFAE dan ekstrak air menunjukkan peningkatan berat badan yang lebih tinggi dibandingkan dengan CT dan metoklopramid. AFAE dan CT memberikan efek yang berlawanan, dimana AFAE menunjukkan efek meningkatkan laktasi dan pertumbuhan anak tikus, sedangkan CT menurunkan efek. 


\section{Pembahasan}

Peningkatan produksi air susu pada tikus menyusui diasumsikan karena peningkatan proliferasi sel pada kelenjar air susu setelah pemberian ekstrak. Herbal galaktogogum dilaporkan memiliki efek dalam proliferasi sel sekretori kelenjar air susu yang digunakan sebagai indikator aktivitas pengeluaran air susu (Capuco, 2010). Penelitian terdahulu menyebutkan bahwa jantung pisang (Musa paradisiaca) memiliki kandungan alkaloid, saponin, glikosida, tanin, flavanoid dan steroid (Mahmood, et.al., 2011). Pada Hibiscus sabdariffa L., keberadaan kandungan seperti saponin, tanin, alkaloid dan flavonoid diasumsikan dengan peningkatan serum prolaktin yang dapat meningkatkan sekresi air susu (Okasha, et.al., 2008). Penelitian Mahmood, et.al. (2012) menunjukkan bahwa ekstrak air jantung pisang (Musa paradisiaca) memiliki efek galaktogogum yang paling tinggi dibandingkan ekstrak petroleum eter dan etanol. Komponen yang diduga bertanggung jawab pada aktifitas galaktogogum pada ekstrak air jantung pisang (Musa paradisiaca) adalah saponin dan tanin yang bersifat polar (Mahmood, et.al., 2011). Perbedaan pelarut akan mempengaruhi kandungan senyawa dalam masing-masing ekstrak. Air dan etanol bersifat polar, sedangkan petroleum eter bersifat non polar. Komponen polar akan terlarut dalam pelarut polar, sehingga yang terlarut dalam ekstrak air merupakan komponen-komponen polar. Pelarut etanol dan air sangat efektif untuk mendapatkan kandungan saponin, flavonoid, tanin dan alkaloid karena keduanya mempunyai kesamaan sebagai pelarut polar (Nurhamdani, 2012).

Penelitian Mahmood, et.al. (2017) selanjutnya menguji efek galaktogogum ekstrak air, aglikon dari ekstrak air dan tanin terkondensasi. Aglikon mengandung senyawa-senyawa seperti triterpen, steroid, antrasena, senyawa yang mengandung gugus fenol, alkohol, aldehid, keton dan eter. Aglikon diketahui memiliki bioavailabilitas lebih baik dalam meningkatkan kemampuan tubuh untuk absorbsi (Mahmood et.al. 2017). Hasil penelitian tersebut menunjukkan penghilangan senyawa glikosida pada ekstrak air tidak berefek pada produksi air susu, sedangkan pada tanin terkondensasi justru menurunkan efek galaktogogum. Tanin diketahui sebagai senyawa anti-nutrisi yang dapat menurunkan pencernaan nutrisi atau menghambat metabolisme (Kawas, et.al., 2010). Tidak ada perbedaan hasil yang signifikan antara ekstrak air dan aglikon dari ekstrak air, sehingga diasumsikan bahwa terdapat kemungkinan bahwa aglikon yang bertanggung jawab terhadap efek galaktogogum. Hal ini sejalan dengan temuan dari beberapa penelitian bahwa bentuk aglikon memiliki kesamaan aktivitas seperti estrogen pada hewan dan manusia (Kang, et.al., 2012).

Dari dua penelitian tersebut dapat disimpulkan bahwa ekstraksi jantung pisang (Musa paradisiaca) menggunakaan pelarut air memberikan efek paling baik dalam meningkatkan produksi susu pada tikus betina dan peningkatan berat badan anak tikus. 


\section{SIMPULAN DAN SARAN}

\section{Simpulan}

Dari penelitian dapat disimpulkan bahwa Ekstrak jantung pisang (Musa paradisiaca) memiliki efek galaktogogum yang dapat digunakan sebagai penambah dan pelancar ASI dan terdapat pengaruh perbedaan pelarut ekstrak jantung pisang (Musa paradisiaca) sebagai galaktogogum, yaitu ekstrak air memberikan efek galaktogogum yang paling besar terutama dalam bentuk aglikon dari ekstrak air.

\section{Saran}

Perlu dilakukan penelitian selanjutnya untuk mengetahui senyawa aktif yang bertanggung jawab terhadap efek galaktogogum dari ekstrak jantung pisang (Musa paradisiaca).

\section{DAFTAR PUSTAKA}

Bekoe, E.O., C. Kitcher, N.A.M. Gyima, G. Schwinger, and M. Frempong, 2018, Medicinal Plants Used as Galactagogues, In PharmacognosyMedicinal Plants, Shagufta Perveen and Areej Al-Taweel (Ed.). IntechOpen. London.

Badan Pusat Statistik. 2018. Statistik Tanaman Buah-buahan dan Sayuran Tahunan Indonesia 2018. Badan Pusat Statistik. Jakarta.

Kang, H.K., Choi, Y.H., Kwon, H., Lee, S.B., Kim, D.H., Sung, C.K., Park, Y.I. \& Dong, M.S, 2012, Estrogenic/Antiestrogenic Activities of a Epimedium koreanum Extract and Its Major Components: in Vitro and in Vivo Studies, Food and Chemical Toxicology, 50(8): 2751-2759.

Kawas, J., Andrade-Montemayor, H. \& Lu, C. 2010. Strategic nutrient supplementation of free ranging goats. Small Ruminant Research, 89(2): 234-243.

Mahmood A, Salihah N, Omar MN, Ngah N, 2017, Lactogenic Effects of Tannin and Aglycone Form of Aqueous Extract (AFAE) from Musa x paradisiaca Flower on Lactating Rats. Malays. Appl. Biol. (2017), 46(3) : 9 -14

Mahmood A., M.N. Omar, and N. Ngah, 2012, Galactogogue Effect of Musax Paradisiaca Flower Extract on Lacting Rats. Asian Pacific Journal of Tropical Medicine : 882-886.

Mahmood A, Ngah N, Omar MN, 2011, Phytochemicals Constituent and Antioxidant Activities in Musa x Paradisiaca flower, Eur J Sci Res 66: 311-318.

Martin, C.R., P.R. Ling, and G.L. Blackburn, 2016, Review of Infant Feeding: Key Features of Breast Milk and Infant Formula, Nutrients 8(5): 279.

Norhamdani, kalsum umi, dan vallencia theola. 2012. Pengaruh ekstrak etanol buah pare (Momordica charantia) sebagai antibakteri terhadap Escherechia coli secara in vitro. Jurnal universitas Brawijaya. Malang 
Okasha MAM, Abu Bakar MS, Bako IG, 2008, Study of The Effect of Aqueous Hibiscus Sabdariffa Linn Seed Extract on Serum Prolactin Level of Lactating Female Albino Rats, Eur J Sci Res; 22: 575- 583.

Padma, L.L., and B.K. Rupalu, 2014, Ricinus communis (Castor): An Overview. International Journal of Research in Pharmacology \& Pharmacotherapeutics 3(2): 136-144.

Penagos Tabares, F., J. V. Bedoya Jaramillo, and Z. T. Ruiz-Cortés, 2014, Pharmacological Overview of Galactogogues. Veterinary Medicine International 2014 (602894).

Sumathy, V., S.J. Lachumy, Z. Zakaria, and S. Sasidharan, 2011, In Vitro Bioactivity and Phytochemical Screening of Musa acuminata Flower, Pharmacologyonline : 118-127.

Zapantis, A., J.G. Steinberg, L. Schilit, 2012, Use of Herbals as Galactagogues. J Pharm Pract. 